S. I. THEOLOGICAL EXPLORATIONS IN TIME AND SPACE

DOI: https://doi.org/10.14428/thl.v4i3.55133

\title{
Craig's Contradictory Kalam: Trouble at the Moment of Creation
}

\author{
ERIK J. WIELENBERG \\ DePauw University \\ ewielenberg@depauw.edu
}

\begin{abstract}
William Lane Craig's much-discussed kalam cosmological argument for God's existence is intended to provide support for a particular theistic explanation of the origin of the universe. I argue here that Craig's theistic account of the origin of the universe entails two contradictions and hence should be rejected. The main contribution of the paper is the identification of some relatively straightforward but previously unrecognized problems in Craig's hypothesis that the beginning of the universe was a temporal effect of a timeless personal cause.
\end{abstract}

Keywords: Timeless God, Kalam, Cosmological argument, William Craig, Agent causation

\section{Introduction}

William Lane Craig's much-discussed kalam cosmological argument for God's existence (KCA) is intended to provide support for a particular theistic explanation of the origin of the universe. I argue here that Craig's theistic account of the origin of the universe entails two contradictions and hence should be rejected. The main contribution of the paper is the identification of some relatively straightforward but previously unrecognized problems in Craig's hypothesis that the beginning of the universe was a temporal effect of a timeless personal cause.

\section{Two Contradictions in Craig's KCA}

The latest version (Craig 2015 and 2018a) of Craig's KCA goes like this: Because the universe began to exist, there must be a cause of the beginning of the universe (call this cause the "first cause"). Because space and time begin when the universe begins, the first cause must transcend space and time; in particular, it must be timeless. It must also be immaterial, very powerful, and it must be a person possessing 
libertarian free will. That the first cause is a person with free will is supposed to explain how a timeless cause can produce a temporal effect: the first cause's "free act of creation is a temporal event simultaneous with the universe's coming into being" (Craig 2015). Craig argues that these considerations suggest that the first cause is a timeless God: "By exercising his causal power, [God] therefore brings it about that a world with a beginning comes to exist. So the cause is eternal, but the effect is not. In this way...it is possible for the temporal universe to have come from an eternal cause: through the free will of a personal Creator" $(2008,154) .{ }^{1}$ Much existent criticism of the KCA focuses on the first two premises of the argument: (1) if the universe began to exist, then the universe has a cause of its beginning and (2) the universe began to exist. I focus here instead on the part of the argument that aims to show that the cause of the universe's beginning is a timeless God.

To see the contradictions entailed by Craig's theistic explanation for the origin of the universe, we must consider God's act of exercising His causal power to bring about a temporal universe. This act is an instance of agent-causation, in which an agent, God, causes an event to occur (see Craig 2002, 102). Let's call the event that God agent-causes 'B'. Let's call God's agent-causing of B 'GA'. GA is itself an event-it is the event that consists of God causally producing B. ${ }^{2}$ Furthermore, as Craig says, GA is simultaneous with the universe's coming into being. Let's call the time at which GA occurs and the universe comes into being ' $t 1$ '. As I noted above, Craig holds that the first cause is timeless: "the cause is eternal, but the effect is not" $(2008,154)$. But that is incompatible with some other claims Craig makes about God. On Craig's view, there are "two phases of God's life, one timeless and one temporal, which are not related to each other as earlier and later" (2001, 235). Furthermore, God is "timeless without the universe and in time with the universe" (2015). When the universe exists, God is temporal rather than timeless. Since time begins with the creation of the universe, if there is some event that occurs at a given time, then the universe exists at that time, and hence God is temporal at that time. GA occurs at $\mathrm{t} 1$, which implies that the universe exists at $t 1$, and hence God is temporal at t1. ${ }^{3}$ Therefore, when God exercises His causal power to create the universe, He is

\footnotetext{
${ }^{1}$ Sometimes Craig describes the first cause as "timeless"; other times as "eternal". I will use 'timeless' throughout the paper and understand it to mean at least existing outside of (physical) time.

${ }^{2}$ For helpful discussion of the structure of agent-causal events, see Bishop 1983, 71-72, O'Connor 1995, 181, O'Connor 2000, 43, Clarke 2003, 187, and Steward 2012, 197. GA cannot be simply B itself, for then there would be no distinction between a given event being agent-caused and that event merely happening (see Chisholm 1964, 10).

${ }^{3}$ Craig and Sinclair make this point themselves: "The time of the first event would be not only the first time at which the universe exists but also...the first time at which God exists" $(2009,196)$.
} 
temporal rather than timeless, and the first cause is therefore temporal rather than timeless. But Craig also says that the first cause must be timeless; otherwise, how could it have the power to create time itself? Craig declares: "For as the cause of space and time, this entity must transcend space and time" $(2008,152)$. And Craig and Sinclair say that "[g]iven that time had a beginning, the cause of the beginning of time must be timeless" $(2009,192)$. God must be temporal at $\mathrm{t} 1$ because the universe exists at $t$; yet He must be timeless at $t 1$ in order to have, at $t 1$, the power to create the universe. Craig's various commitments therefore imply that at $\mathrm{t} 1$, God is both temporal and timeless - a contradiction. ${ }^{4}$

The point can be illustrated with an image that Craig often uses to express his idea of a timeless God creating a temporal universe. The image is that of "a man sitting changelessly from eternity" (2008, 154). According to Craig, this eternally seated man "could freely will to stand up; thus, a temporal effect arises from an eternally existing agent" $(2008,154)$. One misleading aspect of the eternally sitting man image is that the transition from sitting to standing is a process that unfolds over some period of time. When the man is sitting, he causally initiates the process of standing up; as that process progresses, the sitting man gradually becomes a standing man. But now suppose that (i) the man causes the effect of standing up while he is sitting and (ii) all effects produced by the man are produced while he is fully upright. It follows from (i) and (ii) that the man is both seated and fully upright simultaneously - an impossibility. Similarly, on Craig's view, the temporal event of the universe beginning is caused by God in His timeless phase but all temporal events caused by God are caused while He is in his temporal phase. Therefore, God must be in His timeless phase and His temporal phase at once-an impossibility.

This contradiction could be avoided by giving up the claim that God is timeless when GA occurs; perhaps Craig should hold that the first cause is timeless without GA and temporal with GA. However, that renders God in His timeless phase completely causally effete because all of the causal activity that brings the universe into being occurs at $\mathrm{t} 1$, when GA occurs. If Craig's view is that God in His timeless phase makes no causal contribution to the beginning of the universe, then it is misleading for Craig to claim, for example, that God having freedom of the will "enables one to get an effect with a beginning from a permanent, timeless cause" (2015). Similarly, it is difficult to see how to reconcile the causal inertness of God in His timeless phase with Craig and Sinclair's claim that "God's timeless eternity is...causally, but not temporally, prior to the origin of the universe" $(2009,196)$. Note

\footnotetext{
${ }^{4}$ Short version of the first contradiction: the cause of the universe must be timeless; therefore, a temporal being caused the universe.
} 
the difference between (a) the beginning of the universe is caused by an entity in a timeless phase of its existence and (b) the cause of the beginning of universe is temporal when it causes the beginning of the universe and also has a timeless phase in which it causes nothing. Craig's typical descriptions of the first cause suggest (a) rather than (b), and (a) generates the contradiction described above.

Additionally, if God in His timeless phase makes no causal contribution to the beginning of the universe, the KCA provides no reason to believe that God exists in a timeless phase at all. It might be thought that we must posit a timeless God in order to explain where God in His temporal phase comes from, but if timeless God is neither temporally nor causally prior to temporal God there seems to be no meaningful sense in which the former becomes the latter or the latter comes from the former. It is therefore difficult to make sense of Craig's claim that "God entered into time at the moment of creation" $(2001,233)$. With nothing temporally or causally prior to temporal God, we are left with a picture in which the first cause is entirely temporal. ${ }^{5}$

The upshot, therefore, is that the various claims that Craig employs to reach the conclusion that the cause of the universe "must transcend space and time" (2015) together imply a contradiction - that the first cause is both timeless and temporal at t1. To abandon the claim that God in His timeless phase causally contributes to the universe beginning to exist is to abandon the KCA.

There is a second contradiction in Craig's theistic story about the origin of the universe. Consider GA again. As we've seen, GA occurs at t1, the time at which the universe begins to exist. As noted above, Craig holds that time begins when the universe begins (see Craig 2008, 127 and Craig and Sinclair 2009, 130). Therefore, another event that occurs at $\mathrm{t} 1$ is this one: time begins to exist. What is the relationship between GA and time beginning to exist? GA obviously cannot be temporally prior to anything else that happens at $\mathrm{t} 1$, but perhaps GA and time beginning to exist are entirely distinct events and the former is causally prior to the latter. ${ }^{6}$ The problem with that suggestion is that it makes a temporal event-GA-

\footnotetext{
${ }^{5}$ What about God's "timeless intention to create a world with a beginning" (Craig 2002, 102)? On Craig's view, this intention is possessed by God in His timeless phase; might it not make a causal contribution to the beginning of the universe? The answer is no; because all the causal activity that contributes to the beginning of the universe occurs when GA occurs, any divine intention that makes a causal contribution to the beginning of the universe is temporal rather than timeless. If God is temporal rather than timeless when GA occurs, then the complete cause of the beginning of the universe is entirely temporal.

${ }^{6}$ In one place Craig suggests that "God's act of creating is the event cause of the universe's coming into being" (2020), which is suggestive of the possibility that GA is causally prior to time beginning to exist. Here's one version of this possibility, suggested by an anonymous referee: God directly
} 
causally prior to the beginning of time, which is impossible, since it would make the existence of time a prerequisite for an event that is causally prior to the beginning of time and hence would require time to be causally prior to itself. ${ }^{7}$ On the other hand, if time beginning to exist is causally prior to GA, then time exists causally prior to God's act of creating the universe, which conflicts with Craig's theistic hypothesis about the origin of the universe.

A third possibility is that time beginning to exist is a proper part of GA; perhaps time beginning to exist is part of $\mathrm{B}$, so God agent-causes time beginning to exist. But consider this question: does God agent-cause time beginning to exist in His timeless phase or His temporal phase? He cannot be in His timeless phase, since GA occurs at $\mathrm{t} 1$ and, as we've seen, on Craig's view God must be temporal at $\mathrm{t} 1$. But God cannot be temporal either, since in that case the cause of time beginning to exist lies within time itself and, again, Craig and Sinclair insist that "the cause of the beginning of time must be timeless" $(2009,192)$. So it seems that God cannot be the agent-cause of time beginning to exist.

The most plausible option, therefore, is that GA and time beginning to exist are the same event; GA is the beginning of time. ${ }^{8}$ Accordingly, I shall suppose for the remainder of this discussion that $\mathrm{GA}=$ time beginning to exist.

As noted above, GA is an event with a somewhat complex structure; it is the event consisting of God agent-causing B. GA does not have a cause. It is a causing; it is not itself caused. So if GA and time beginning to exist are the same event, then time beginning to exist is uncaused. But that violates a fundamental metaphysical principle that drives the $\mathrm{KCA}$ - the principle that "being cannot come from nonbeing; something cannot come into existence uncaused from nothing. The principle...applies to all of reality" (Craig 2008, 114). Time is part of reality, and so, by Craig's principle, the beginning of time must have a cause. As Craig says, "[ $t]$ here

\footnotetext{
agent-causes in Himself an undertaking to create the universe (note: here, the undertaking is understood to be the effect of God's agent-causal activity); that undertaking in turn event-causes the beginning of the universe (including time). The problem with that proposal is that God's undertaking must be a temporal event and so cannot be causally prior to the beginning of time.

${ }^{7}$ In this scenario, time would engage in "self-creation", which Craig describes as "metaphysically absurd" $(2008,152)$.

${ }^{8}$ Some of Craig's own remarks point in this direction: "The event of the universe's coming into being cannot be an instance of state-state causation...neither can it be an instance of state-event causation... [t] he best way out of this dilemma is agent causation" $(2002,102)$. The passage suggests that the event of the universe's coming into being - and hence of time's coming into being - is an instance of agent-causation. Craig often writes as if the beginning of time is agent-caused by the First Cause (e.g. Craig 1991) - as if God is what Smith calls an "originating cause" $(1996,170)$ of time but that is the "third possibility" considered and rejected in the main text.
} 
must be an absolutely first event, before which there was no change, no previous event. We know that this first event must have been caused" $(2008,153)$. GA is that first event-it is an event that "entails... an intrinsic change on God's part" (Craig $2002,102)$ and before which there is no change - and yet it is uncaused. Therefore, Craig's commitments imply that the absolutely first event is both caused and uncaused - another contradiction. ${ }^{9}$

It may be tempting here to deny that GA is uncaused on the grounds that God agent-causes it. But this introduces another event, God's agent-causing of GA (call that event ' $G A^{* \prime}$ ) which now appears to be the beginning of time, and which has no cause. If we suppose that God agent-causes GA* as well, the same problem appears again, and we are headed for an actual infinite series of divine agent-causal events (see O'Connor 2000,58). Because Craig rejects the possibility of such actual infinite series, he must reject this possibility (see Craig 2018a, 390-396). ${ }^{10}$

Another way to deny that GA is uncaused is to hold that there is some property or state of God in His timeless condition that causes GA; call such a state 'S'. Craig says that God "freely and eternally intends to create a world with a beginning" $(2008,154)$. Perhaps this eternal divine intention causes GA? One problem with this suggestion is that it would require a timeless state, $S$, to bring about a temporal event, GA. Craig explains why this is implausible: "the cause is a timeless state but the effect is an event that occurred at a specific moment in the finite past. Such state/event causation doesn't seem to make sense, since a state sufficient for the existence of its effect should have a state as its effect" (2008,54; see also Morriston 2000, 165, and Morriston 2002, 105-107). Accordingly, Craig says that God's eternally willing to create the universe is not sufficient for the existence of the universe $(2002,102)$. On Craig's view, we seem to be stuck with GA itself as the uncaused beginning of time - and yet we also seem to be stuck with the beginning of time having a cause.

It is worth considering one final way of evading this second contradiction. In a footnote, Craig and Sinclair mention (but do not endorse) the position that an agent's causing some effect "is not itself an event" (2009, 194, n. 101). If GA is not an event, then the question of the relationship between the event of GA and the event of time beginning does not arise. Now, the claim that God's act of creating the universe is not an event is puzzling on its face - this act certainly seems to be something that happens and so counts as an event in the ordinary sense of the term. More

\footnotetext{
9 Short version of the second contradiction: The beginning of time must have a cause; therefore, the beginning of time $=$ an uncaused agent-causal event.

${ }^{10}$ In a footnote, Craig and Sinclair (2009) explicitly endorse the position that agent-causings are themselves uncaused (194, note 101).
} 
importantly, in one of his most detailed discussions of how God causes the beginning of the universe, Craig says that in order for the universe to exist there must be "a basic action on the part of [God], an undertaking or endeavoring or exercise of [God's] causal powers... [t] hat entails...an intrinsic change on God's part" $(2002,102)$. In that passage Craig appears to classify God's exercise of His agentcausal power as both (i) an action performed by God and (ii) entailing an intrinsic change in God. That GA entails an intrinsic change in God suggests that it is an event. And as I noted at the outset, Craig says that God's "free act of creation is a temporal event" (2015, emphasis added). Elsewhere, Craig says that "God's act of creating is the event cause of the universe's coming into being" (2020), which also suggests that God's act of creating the universe-GA-is an event. ${ }^{11}$ Therefore, Craig cannot consistently hold that GA is not an event. Craig's view appears to imply that GA is an event and it is both caused and uncaused - a contradiction.

\section{Conclusion}

In one place, Craig remarks: "I well recall thinking, as I began to study the kalam cosmological argument, that all of the alternatives with respect to the universe's existence...were so bizarre that the most reasonable option seemed to be that nothing exists!" $(2002,97)$. Craig's point here is well-taken; clearly something bizarre and unusual is involved in the existence of the universe. But it turns out that Craig's theistic explanation for the origin of the universe is logically contradictory. It entails that the first cause is both timeless and temporal at $\mathrm{t} 1$, and it entails that the beginning of time both has a cause and is an uncaused agent-causal event. Bizarre is one thing; logically impossible is another. If the argument of this paper is correct, then Craig's theistic explanation is not merely bizarre but also logically impossible and so should be set aside. ${ }^{12}$

${ }^{11}$ Craig seems not to be entirely consistent on this point. In responding to Smith, he asserts that "[t]he expression 'God's willing that the Big Bang occur' properly describes an action, not an event" (2018b, 344). Yet Craig holds that this divine willing is simultaneous with the universe beginning to exist, so it is clearly an event in the ordinary sense of something that happens. Remarkably, in the paragraph immediately preceding the one in which he says that God's willing is an action and not an event, Craig writes: "God's willing and the Big Bang are both events which occur" (2018b, 343).

12 I am grateful to Jeff Dunn, Wes Morriston, and the students in my spring 2020 Philosophy of Religion course at DePauw University for helpful discussion of some of the issues raised in this paper. I am particularly grateful to one student in that course, Sophia Meadows, who asked a question that inspired the writing of this paper. I am also grateful to Morriston, Felipe Leon, and two anonymous referees for feedback on earlier versions of the paper. 


\section{Bibliography}

Bishop, John. (1983). "Agent-Causation", Mind 92: 365: 61-79. https://doi.org/10.1093/mind/XCII.365.61.

Chisholm, Roderick. (1964). Human Freedom and the Self. University of Kansas.

Clarke, Randolph. (2003). Libertarian Accounts of Free Will. Oxford: Oxford University Press. https://doi.org/10.1093/019515987X.001.0001.

Craig, William Lane. (1991). "The Kalam Cosmological Argument and the Hypothesis of a Quiescent Universe", Faith and Philosophy 8:1: 104-108. https://doi.org/10.5840/faithphil1991819.

Craig, William Lane. (2001). Time and Eternity: Exploring God's Relationship to Time. Wheaton, IL: Crossway. https://doi.org/10.1007/978-94-017-1715-1.

Craig, William Lane. (2002). "Must the Beginning of the Universe Have a Personal Cause?: A Rejoinder", Faith and Philosophy 19:1: 94-105. https://doi.org/10.5840/faithphil20021917.

Craig, William Lane. (2008). Reasonable Faith: Christian Truth and Apologetics, $3^{\text {rd }}$ edition. Wheaton, IL: Crossway.

Craig, William Lane, and Sinclair, James D. (2009). "The Kalam Cosmological Argument", in The Blackwell Companion to Natural Theology, edited by W.L. Craig and J.P. Moreland (Malden, MA: Blackwell), pp. 101-201. https://doi.org/10.1002/9781444308334.ch3.

Craig, William Lane. (2015). "The Kalam Cosmological Argument". $<$ https://www.reasonablefaith.org/writings/popular-writings/existence-natureof-god/the-kalam-cosmological-argument/> [Accessed 2/1/20]

Craig, William Lane. (2018a). "The Kalam Cosmological Argument", in Two Dozen (or so) Arguments for God, edited by J. Walls and T. Dougherty (Oxford: Oxford University Press), pp. 389-405.

Craig, William Lane. (2018b). "Beyond the Big Bang", in The Kalam Cosmological Argument, Volume 2: Scientific Evidence for the Beginning of the Universe, edited by P. Copan and W.L. Craig (New York: Bloomsbury), pp. 333-352.

Craig, William Lane. (2020). "Creation and Simultaneous Causation". $<$ https://www.reasonablefaith.org/writings/question-answer/creation-andsimultaneous-causation> [Accessed 6/30/20]

Morriston, Wes. (2000). "Must the Beginning of the Universe Have a Personal Cause?: A Critical Examination of the Kalam Cosmological Argument", Faith and Philosophy 17:2: 149-169. https://doi.org/10.5840/faithphil200017215. 
Morriston, Wes. (2002). "A Critical Examination of the Kalam Cosmological Argument", in God Matters, edited by R. Martin and C. Bernard (London: Longman), pp. 95-108.

O'Connor, Timothy. (1995). "Agent Causation", in Agents, Causes, and Events: Essays on Indeterminism and Free Will, edited by T. O'Connor (Oxford: Oxford University Press), pp. 173-200.

O'Connor, Timothy. (2000). Persons and Causes: The Metaphysics of Free Will. Oxford: Oxford University Press.

Smith, Quentin. (1996). "Causation and the Logical Impossibility of a Divine Cause", Philosophical Topics 24:1: 169-191. https://doi.org/10.5840/philtopics199624114.

Steward, Helen. (2012). A Metaphysics for Freedom. Oxford: Oxford University Press. https://doi.org/10.1093/acprof:0so/9780199552054.001.0001.

Published Online: October 09, 2020 